\title{
A SÓ- ÉS CUKORMENTES TÁPLÁLKOZÁS KVALITATÍV VIZSGÁLATA A ZÖLDSÉGKONZERVEK PIACÁN
}

\author{
- \\ QUALITATIVE INVESTIGATION OF SALT AND SUGAR FREE NUTRITION \\ IN THE CANNED VEGETABLE MARKET \\ $-1$ \\ BOROS, HENRIETTA MÓNIKA \\ FEHÉR, ANDRÁS

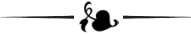 \\ Debreceni Egyetem, Gazdaságtudományi Kar, Marketing és Kereskedelem Intézet \\ (University of Debrecen, Faculty of Economics and Business, Institute of Marketing and Commerce) \\ H-4032 Debrecen, Böszörményi út 138. \\ e-mail: borosh19@gmail.com
}

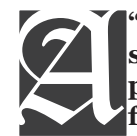

"Free from" products as important components of a health-conscious diet are prevalent on store shelves. Our research is based on the analysis of the market situation and introduction possibilities of a potential canned vegetable that can even satisfy the needs of consumers for salt and sugar free meals. Secondary data and information collection provided the basis for further research. In the primary research, we used three qualitative methods, which were netnographic examination, expert interview, and focus group research. In the course of netnography, we examined consumer needs for salt and sugar free canned food on the Internet, mainly on social media, based on pre-collected keywords. The interview with an expert in the canning industry focused on the specificity of canned food and the position of "free from" canned food. Focus group research was composed to learn about the perceptions of university students about both canned food and their customers alike. Among other things, we have shed light on the fact that consumers associate the expression "free from" with the word health, but emphasizing "free from" nature of the product can create a sense of lack. Examining "free from" canned food, we found that young, time constrained, health-conscious consumers can be the target group. Due to the target market, we recommend promoting it on online platforms, where it would even be advisable to use educational campaigns.

KuLCSSZAVAK: konzerv, sómentes, cukormentes, táplálkozás, fogyasztói magatartás

JEL-KóDOK (JEL CODES): M31, Q13

DOI: https://doi.org/10.20494/TM/8/1/6

\section{BEVEZETÉS - INTRODUCTION}

A tanulmány hátterében egy olyan konzervipari termékcsalád eszméje áll, amely kielégítheti a só- és cukormentes táplálkozáshoz füződő fogyasztói igényeket. Nem egy adott élelmiszer piaci bevezetésének szakaszait vizsgáljuk, hanem a meglévő szakirodalmi információk és
KEYWORDS: canned food, salt free, sugar free, nutrition, consumer behavior

szakértői, fogyasztói meglátások szerint elemezzük az ilyen típusú termékek piaci helyzetét és bevezetésének lehetőségeit hazánkban. Az elmúlt évek során sorra jelentek meg az úgynevezett „mentes”, másnéven „free from” termékek, amelyeket a fogyasztók vélhetően az egészségtudatos táplálkozás fogalmához kötnek. A mentesség széleskörüen magába foglalhatja az olyan termékeket, amelyek akár 
laktóztól, gluténtől, cukortól vagy egyéb anyagoktól, hozzávalóktól mentesek.

Már TÖRŐCSIK (2011) is megfogalmazta, hogy az egészségtudatos életmód gyakorlatai megatrendekké váltak és ez az idő múlásával csak erősödött (PAGLIARO, 2019). A zöldségek és gyümölcsök, mint egészségtudatos életmódba bevonható élelmiszerek, vásárlásakor választhatjuk a friss, a fagyasztott, vagy akár a konzerv változatukat is. Az utóbbit só és cukor hozzáadásával készítik el a gyártók, azonban ezek kihagyása esetén mentes konzervekról beszélhetünk, amelyek a kutatásunk témáját is képezik. A konzervekről számos tévhit él a társadalomban, így lényeges lenne a mentes zöldségkonzervek megfelelő kommunikációjának kialakítása, a félreértések elkerülése végett.

A kutatómunka elején három kérdést fogalmaztunk meg, amelyekre a szekunder és primer vizsgálatok segítségével kerestük a választ, ezek pedig az alábbiak voltak:

- Mi az egyetemisták álláspontja a só- és cukormentes élelmiszereket illetően?

- Kik vásárolnák és fogyasztanák a későbbiekben a só- és cukormentes zöldségkonzerveket?

- Milyen módon lehetne kommunikálni a mentes konzervtermékeket?

\section{SZAKIRODALMI ÁTTEKINTÉS - LITERATURE REVIEW}

Ebben a fejezetben elemezzük a só- és cukormentes táplálkozással, illetve a mentes konzervekkel kapcsolatos szakirodalmi információkat.

\subsection{Só- és cukormentes táplálkozás - Salt and Sugar Free Diet}

A „2020 Livewell-program” (WWF, 2020) egyik alapelve is kiemeli: az egészségmegőrzés céljából mérsékelni kell a só- és cukorfogyasztást. Az ajánlott napi mennyiség 25-36 gramm cukor lenne, azonban a legutóbbi releváns adatok szerint a magyar nők körülbelül 45,5 $\mathrm{g}$, a férfiak 52,7 g cukrot fogyasztanak naponta. Konyhasóból pedig elegendő lenne naponta nagyjából 5 g-ot bevinni a szervezetünkbe, azonban a magyar társadalom mégis 2-3-szorosan a napi ajánlás felett fogyaszt (OGYÉI, 2014; AHA, 2020). Az 1. ábra ezek alapján szemlélteti a magyar lakosság só- és cukorfogyasztását.

1. ÁBRA

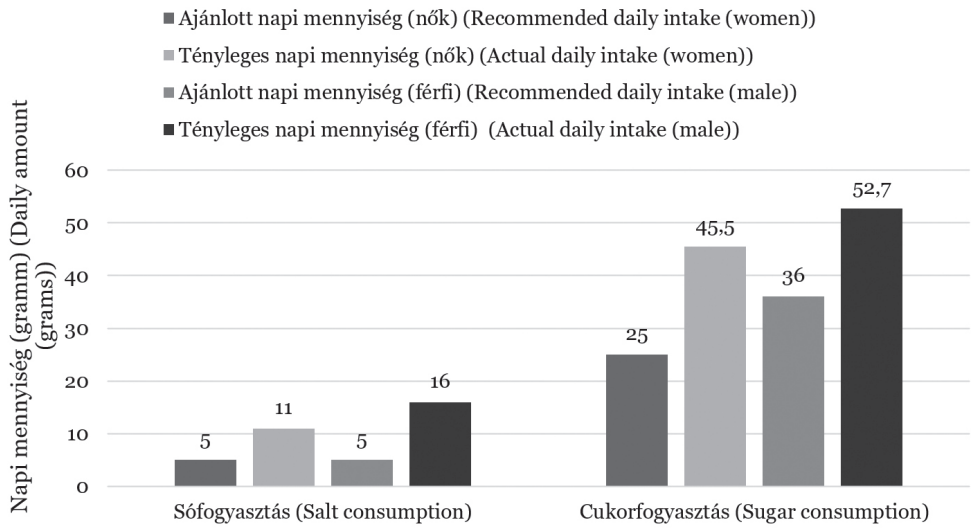

Ajánlott és tényleges só- és cukorfogyasztási mennyiségek (Recommended and Actual Salt and Sugar Intake)

Forrás (Source): Saját szerkesztés, OGYÉI (2014) és AHA (2020) alapján (Authors' own compilation based on OGYÉI (2014) and AHA (2020)) 
Az egészségtudatos táplálkozáson túl a civilizációs betegségek is hátterében állhatnak a mentes termékek megjelenésének (PRIVEN et al., 2015). A társadalom elkezdte felismerni az élelmiszerallergiákat és az intoleranciákat, ezáltal teret adva a só- és cukormentes élelmiszereknek (TÖRÓCSIK, 2011). A legutóbbi adatok szerint Magyarországon több mint 1,1 millió felnőtt és több mint 5 ezer gyermek él cukorbetegséggel, valamint a társadalmunk 30,9\%át érinti a magas vérnyomás, amely akár a túlzott sófogyasztás következménye is lehet (KSH, 2019a; KSH, 2019b). Habár meg kell jegyezni, hogy egyes mentes élelmiszerek (pl. laktóz- vagy gluténmentes termékek) fogyasztásával egy átlagos ember megvonhat magától olyan tápanyagokat, amelyekre szüksége lehet (CSAPÓNÉ RISKÓ és PÉNTEK, 2018).

A mentes élelmiszerek tulajdonképpen funkcionális termékek, ugyanis négyféle eljárás során készülhetnek el, ezek egyike pedig az egészségre kedvezőtlen hatású összetevők kivonásával jár (LEHOTA, 2001). A funkcionális élelmiszerekról még nem jutott el elegendő információ a fogyasztók nagy részéhez vagy nem észlelték olyan módon, hogy hajlandók legyenek változtatni az étkezési szokásaikon vagy tudatos vásárlásba kezdjenek (SZAKÁLY et al., 2014; LIPOWSKI és BONDOS, 2018). Továbbá a magyar társadalom számára az íz és élvezeti érték prioritásban részesül az élelmiszerek egészségességével szemben (SZAKÁLY et al., 2014). Így a társadalmunk csupán $14 \%$-a vásárolná meg azokat az élelmiszereket is, amelyek hozzájárulnak az egészségükhöz, de az ízlésüknek nem felelnek meg (SZAKÁLY, 2008).

A vásárlók igénylik a termékinformációk pontos és világos feltűntetését (HOEK et al., 2017; KOCSIS, 2017). Az élelmiszerpiacon található számos mentes kategóriás termékek esetében, viszont a kutatások feltárták, hogy a termékjelölések ellenkező, negatív hatást válthatnak ki a fogyasztókból. Tehát a sómentesség erőteljes hangsúlyozása sok esetben a sós íz hiányát eredményezheti (LIEM et al., 2012).

\subsection{A konzervtermékek és fogyasztói megítélésük - Canned Products and Their Consumer Perception}

A konzerveknek nincs pontos definíciója és elfogadott meghatározása, mégis hétköznapi kifejezésnek számít. Azonban TEMESI és munkatársai (2010:34) megfogalmazása, miszerint a konzerv „olyan élelmiszer, amelynek a tartósítása fémdobozban történik és hosszan eltartható" már egy szakmailag releváns definíció.

A fogyasztók leginkább olyan termékek közé sorolják a konzerveket, mint a késztermékek, a rágcsálni valók, illetve a szénsavas üdítők, nem pedig az „egészséges” élelmiszerek csoportjába (KOHLNÉ PAPP és GYÁNYI, 2017). Az asszociációk akár kialakulhattak a köztudatban élő tévhitekből is, ugyanis a konzervekről hamis és negatív információk terjednek a fogyasztók köreiben (HORVÁTH, 2018). Mégis a magyar társadalom tartósított zöldség, illetve gyümölcs- és zöldségkészítmény fogyasztása pozitívan alakul. A zöldségkészítmények fogyasztása ugrásszerüen megnőtt az utóbbi évek során. 2017-ben fejenként 8,1 kg tartósított zöldséget, illetve zöldségkészítményt fogyasztottunk és ez 2018-ra 11,1 kg-ra nőtt. A legutóbbi, 2019-es adatok pedig $12 \mathrm{~kg}$-ot mutatnak (KSH, 2019c).

A zöldségkonzerveket vásárlók leginkább a 30-39 éves korosztályból kerülnek ki, amely azzal magyarázható, hogy e termékek időmegtakarító funkcióval rendelkeznek és ez leginkább ebben a körben kap nagy szerepet (TEMESI, 2010). Ennél a generációnál pedig még sikerrel járhatnak az online kommunikációs eszközök az információközlésben (KÉRI, 2018; LIPOWSKI és BONDOS, 2018). Jelentős só- és cukormentes vagyis funkcionális konzervipari célcsoportoknak tekinthetjük az „egészségre nagy hangsúlyt fektető nőket” és a ,jobb módú, erős szervezetre vágyó munkásokat” is (TEMESI és SZENTE, 2013:52). 


\section{ANYAg ÉS MÓDSZER - MATERIAL AND METHOD}

A kutatás első fázisában szekunder adat- és információgyüjtést hajtottuk végre, ahol releváns, illetve aktuális publikációkat, adatbázisokat gyüjtöttünk össze a vizsgálat biztos alapokra helyezése érdekében.

Később a primer adatgyüjtést három kvalitatív módszerrel végeztük, ami miatt a kapott eredmények feltáró jellegüek és nem reprezentatívak a társadalomra.

A netnográfiai vizsgálat 2020. végén történt, amely alapja a szekunder kutatás volt. Forgatókönyvben határoztuk meg többek között a kutatás időtartamát, kérdéseit, módját és az elemzésbe bevonni kívánt felületeket. Továbbá a legfontosabb kulcsszavakat is öszszegyűjtöttük, amiben a Google keresőjének javaslatai is szerepeltek (pl. sómentes, cukor helyett, konzerv, egészségtudatos táplálkozás). A kutatás során a mentes élelmiszerek, illetve a só- és cukormentes konzervek piaci igényére kerestük a választ. A bevont online felületek a Google, a Facebook, az Instagram és a Pinterest volt, majd ezek keresőmotorjaiba illesztettük be a meghatározott kulcsszavakat és figyeltük meg a találati számokat. Ezen túl egységesen a felkínált találati listák első 20 elemét vizsgáltuk meg, amely saját kutatói döntés volt. Hangsúlyozzuk, tisztában vagyunk azzal a ténynyel, hogy egyes kulcsszavak lényegesen több találatot eredményezhetnek. A találatok között a hirdetéseket nem elemeztük. A blog- és fórumbejegyzések esetében az adott oldalakon tovább folyt a keresés a megadott kulcsszavakkal. A kutatás alatt passzív megfigyelő szerepet töltöttünk be.

A szakértői interjú alapja a szakirodalmi áttekintés és a netnográfiai kutatás volt. A kérdéssor kitért a konzervipar sajátosságaira, illetve a - cukortól, sótól és egyéb adalékoktól - mentes élelmiszerek közkedveltségére. Továbbá néhány, a piacot befolyásoló tényezőról, a bevezetni kívánt konzervipari termékek gátló tényezőiről és lehetőségeiről folytattunk diskurzust. Az interjúalanyunk tapasztalt konzervipari szakértő volt. A COVID-19 teremtette helyzethez igazodva az interjú online felületen valósult meg 2020. végén.

Végül elkészítettünk egy fókuszcsoportos kutatást is, amely alanyait és forgatókönyvét az előzetes kutatások alapján határoztuk meg. A kutatás nyolc résztvevője mind 20-27 év közötti egyetemista volt, fele férfi, fele nő arányban, ahol a tagok nem ismerték egymást. Közülük részt vett cukorbeteg és refluxos személy egyaránt. A lebonyolítás körülbelül egy órát vett igénybe 2021. elején. A már említett járványhelyzethez igazodva, a kutatás szintén online felületen zajlott le. A fókuszcsoportos kutatás nyitott kérdései mellett szerepelt asszociáció, márka-megszemélyesítés - ahol egy-egy fogyasztói típust kellett jellemezni - és szituációs feladat egyaránt.

\section{EREDMÉNYEK - RESUlts}

A következőkben a primer adatgyüjtések, tehát a netnográfia, a szakértői interjú és a fókuszcsoportos kutatás eredményeit mutatjuk be.

\subsection{A netnográfiai kutatás elemzése - Analysis of the Netnographic Research}

A netnográfiai kutatás során az interneten figyeltük meg a fogyasztói véleményeket a mentes élelmiszerekre és a konzervekre vonatkozóan.

Az előzetesen meghatározott kulcsszavakat, kifejezéseket magyar és angol nyelven is vizsgáltuk. A Google kereséseknél fontos kiemelni, hogy magára a „konzerv” kifejezésre 1650000 találatot kaptunk (“canned food": 26700 000), amely hátterében leginkább a webes áruházak álltak, amelyeket szintén tanulmányoztunk. A „só” és „cukor” (1 820000 ooo és 9980000 találat) szavak pedig különböző honlapokhoz irányították a kutatást, ahol a cikkek és blogbejegyzések információkat közölnek, akár a túlzott fogyasztás negatív következményeiről is. A vizsgálat során mégis a cukor nélküli („cukormentes”: 1010 ooo; „cukor nélkül”: 355000 találat) cikkekre és bejegyzésekre mutatkozott nagyobb kínálat, illetve hozzászólási hajlandóság, nem pedig a só nélküli („sómentes”: 34 200; „só nélkül”: 29900 találat) témákra.

Magyarország legismertebb közösségi oldalai a RESEARCHCENTER (2020) felmérése alapján többek között, a Facebook, az Instagram és a Pinterest volt. A Google és a három közös- 
ségi oldal keresőmotorjai által kapott találatokat, bejegyzéseket és hozzászólásokat összegyüjtöttük. Az olvasottakat csoportosítottuk és a súlyuk alapján ábrázoltuk általános monda- tokkal, mindezt a szófelhők példájára egy úgynevezett véleményfelhő illusztrálja a 2. ábrán.

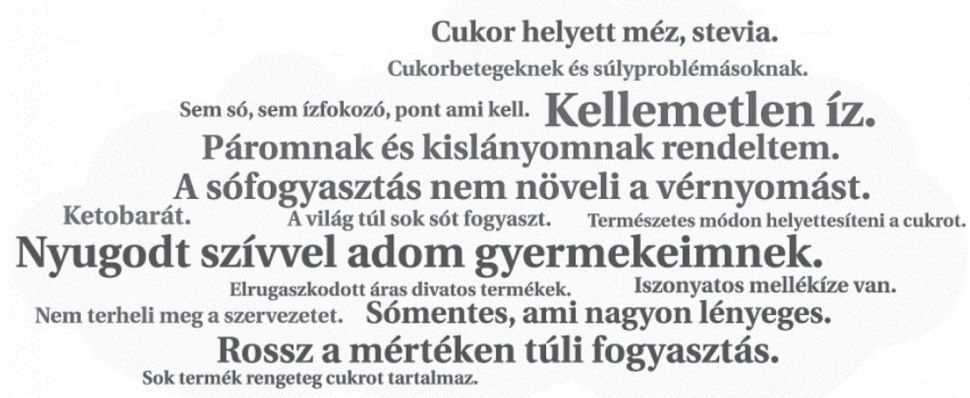

2. ÁBRA

A só- és cukormentes táplálkozásról alkotott vélemények

FIG. 2

\section{(Opinions on a Salt and Sugar Free Diet)}

Forrás (Source): Saját szerkesztés a netnográfiai kutatás alapján, 2021 (Authors' own compilation based on the netnographic research, 2021)

Megjegyzés (Note): A véleményfelhőben szereplő mondatok mérete arányos a csoportok említésének gyakoriságával.

(The size of the sentences in the cloud of opinion is proportional to the frequency with which the groups are mentioned.)

Számos vélemény kitért a só és cukor helyettesítésének, csökkentésének vagy megvonásának szükségességére és módjaira. Említették többek között a társadalomban fennálló olyan táplálkozási vagy egészségügyi problémákat, mint a cukorbetegség. Továbbá az egészség megőrzése, illetve a divatból és fogyás céljából alkalmazott diéták is terítékre kerültek. Azonban a családjuk megfelelő táplálkozását is szem előtt tartják a hozzászólók, bár megfigyelhető, hogy nehezen igazodnak el a temérdek információ között.

A netnográfiás vizsgálatból leszűrtük még, hogy a konzervekről ritkán alkotnak véleményt a felhasználók. Leginkább olyan kommenteket olvashattunk a blogok és közösségi oldalak bejegyzései alatt, amelyek a konzervdobozok újrahasznosításának módját célozták meg.

A közösségi oldalakon megfigyeltük az egészség, a táplálkozás és a konzervek területén az online tér aktív használóit, akik a vállalatok (élelmiszergyártók, cukrászdák, éttermek), a magánszemélyek (átlagos fogyasztók, akik több esetben hozzászólások formájában nyilvánulnak meg), illetve a tapasztalt internethasználók (dietetikusok, tanácsadók, véleményvezérek) voltak. A három csoport tagjai pedig leginkább egészséges receptötleteket, diétás étrendeket, illetve egyéb tanácsokat, praktikákat osztanak meg a zöldségkonzerveket érintően.

\subsection{A szakértôi interjú elemzése - Analysis of the Expert Interview}

A konzerviparban jártas szakértő röviden ismertette a konzervek előállítását: „A felületkezelt konzervdobozokba belekerül a friss zöldség, amelyet felöntenek sót és cukrot tartalmazó ivóvízzel, majd a konzervek hőkezelésen esnek át. Így tartósítószer és egyéb anyagok nélkül steril környezetben párolják és hővel kezelik a zöldségeket.”. A magyarázat szükségességét a társadalomban fennálló tévhitek igazolják: „tartósítószert tartalmaz”, „nincs benne tápérték”, „szülő, nagyszülő terméke”. Az utóbbi sztereotípia ellenére a szakértő a fiatal felnőtt réteget tekinti megfelelő célcsoportnak a speciális konzervtermékeket illetően, ugyanis a konzerv gyors megoldást nyújthat számukra a napi teendők mellett.

A mentes zöldségkonzervek cukor és só hozzáadása nélkül készülnek, ennek ellenére magasabb áron szerepelhetnek a boltok polcain. A szakértő részletesen kifejtette, hogy az elvárt íz érdekében szükséges néhány zöldséget édesebb, erőteljesebb ízủ fajtával helyettesíte- 
ni. Ezáltal bizonyos alapanyagok ára magasabb lesz, amivel a konzervtermékek ára is nő.

A szakértő véleménye szerint a só- és cukormentes konzervek imázsának kialakítása során negatív hatásokat vonhat maga után a só vagy cukor nélkülözésének kiemelése. Olykor a fogyasztó társíthatja a rossz ízt, a sósság vagy az édesség hiányát az említett termékekhez. Így a „mentes” vagy a „free from” kifejezések helyett sokkal inkább olyan üzenetekkel lenne célszerü értékesíteni, amelyekkel frissességet, finom ízt és egészséget társítanak majd a vásárlók a mentes konzervekhez.

Amikor a piaci igényról kérdeztük a konzervipari szakembert, akkor három irányból kaptunk megközelítést. Először is a magyar kereskedők pozitívan reagálhatnak a mentes termékek innovációira, hiszen azt tapasztalják, hogy egyre több vásárló vesz mentes élelmiszereket. Másodszor az interjúalany által ismert számos piackutatás is igazolni tudja a „superfood"-ok, a funkcionális élelmiszerek és a speciális termékek iránti igényt. Továbbá a mentes konzervek fogyasztói lehetnek a táplálkozási vagy különböző egészségügyi problémával, érzékenységgel együtt élő csoportok is (pl. diabétesz), amelyekre segítséget nyújthat a cukor- és sómentes termék. A célcsoportot alkothatják még az egészségtudatosan táplálkozó rétegek, vagy a divatból és kíváncsiságból vásárló csoportok.

Az üzleteken belüli elhelyezés fontos kérdést foglal magába, ugyanis ma már lehetőség van elkülönített polcokon a reform étkezéshez kapcsolódó termékeknek, a modern ételeknek és a speciális élelmiszereknek a kihelyezésére. Ezzel a só- és cukormentes konzervek elhelyezése is szélesebb palettán mozoghat. Két opciót tárgyalt a megkérdezett szakértő, az egyik a termék kihelyezése volt a többi konzerv mellé. Ez lehetőséget nyújthat a vásárlóknak a könynyebb megtalálásban. Ráadásul a kipróbálásra is motiválhatja őket, ugyanis a vásárló összehasonlíthatja az átlag konzerveket a só- és cukormentes társaikkal. A másik választás a speciális, elkülönített polcokon való megjelenés, mivel a mentes konzerv megoldást nyújthat az egészségtudatos vásárlóknak és a speciális igényekkel, egészségügyi problémákkal (pl. cukorbetegség) együtt élőknek egyaránt. Továbbá azok is megtalálják a mentes konzerveket, akik a divat miatt vagy az újdonság keresésének vágyával tévednek ezekhez a polcokhoz, azonban itt mégis kevesebben keresik és vásárolják a termékeket.

Összegzésképpen a szakértő szerint bonyolult lehet az élelmiszerek mentességének értelmezése, mert a fogyasztók nem feltétlenül tudják, hogy a gyártók milyen megoldásokkal és helyettesítésekkel érik el a várt eredményt. Ebből kifolyólag a szakértő fontosnak tekinti a társadalom edukációját. Emellett számos előnnyel szolgálhat a gyártók számára, hogy a kereskedők potenciált látnak a mentes termékekben, illetve a fogyasztók keresik az ilyen típusú élelmiszereket.

\subsection{A fókuszesoportos vizsgálat elemzése - Analysis of the Focus Group}

A szakértői interjún elhangzottak alapján a fiatal felnőtt kategóriát határoztuk meg célcsoportnak. Azonban a fókuszcsoportos kutatás résztvevőihez ezt tovább konkretizáltuk az egyetemisták csoportjára, akik nagy hajlandósággal vásárolnak és fogyasztanak konzervtermékeket, fóleg, ha gyermekkorban is látták ezt a mintát (DRURY et al., 2018).

Elöször asszociációs feladatot kaptak az alanyok, amely célja volt feltárni mi jut eszükbe az alábbi szavakról különösebb gondolkodás nélkül. A „zöldség”, „gyümölcs” és „mentes” kifejezéseket egyértelműen az egészségtudatossághoz kapcsolták a résztvevők, míg a „só” és a „cukor” szavak a túlzott fogyasztás negatívumaiként jelentek meg. Később a „konzerv” hallatán a fókuszcsoport többsége konkrétan a kukoricakonzervre asszociált, azonban a tartóssággal és az apokalipszist bemutató filmekkel is társították azt.

Az asszociáció után a só- és cukormentes termékek témakörét vizsgáltuk a csoporttal. Az egyetemisták szubjektív megítélése alapján több cukrot és sót fogyasztanak, mint kellene. Viszont egyhangúan kijelentették, hogy ha minden étkezésnél nem is, de nassoláskor inkább választják/választanák a mentes vagy só- és cukortartalmában csökkentett élelmiszereket. Szerintük ezek a termékek alapját nyújthatják az egészségtudatos táplálkozásnak, a speciális étrendeknek, illetve a népszerü divatdiétáknak. 
A csoport tagjai szerint a só- és cukormentes termékeket leginkább ez a két típus keresi rendszeresen:

- Szigorúan korlátozva, minimálisan fogyasztanak sót és/vagy cukrot: leginkább rajtuk kívülálló okokból, betegségükből, érzékenységükből (pl. diabétesz, anyagcsere problémák) adódóan táplálkoznak a hagyományostól eltérően.

- Direkt módon nem fogyasztanak sót és/ vagy cukrot: tudatosan nélkülözik a sót és cukrot, ennek hátterében állhat az ideális külső elérése vagy az egészségtudatos életmód megvalósítása is.

$\mathrm{Az}$ egyetemisták egyetértettek abban is, hogy a mentes termékek ára átlagosan magasabb, mint a szokásos termékeké. A magasabb ár pedig szerintük csupán marketingfogás és nem lenne szükség ilyen mértékű árkülönbségre. Az előbb említett két csoport pedig hajlandó vagy éppen kénytelen megfizetni a termékek felárát.

A zöldségkonzervekről általánosságban is megkérdeztük a résztvevőket, így megtudtuk, hogy nem ismerik sok típusát vagy felhasználási módját. Azonban a konzervtermékeket illető előnyökhöz sorolták, hogy időt spórolhatnak általuk, könnyü a felhasználásuk és sokáig elállnak. Az említett negatívumai általában a felbontás nehézsége, illetve a friss zöldségekkel szembeni elképzelt hátrányok (pl. tápanyagtartalma alacsonyabb lehet) voltak. Ezután megkértük, hogy említsenek konzervmárkákat, ahol a Globus és a Bonduelle kimagasló helyen szerepelt. Végül támogatott felidézéssel vizsgáltuk tovább a hazánkban elérhető konzervmárkák ismertségét, ahol fóleg a Happy-frucht és az Eko márka volt közismert a már felsoroltakon túl.

A megfelelő design vagy csomagolás kigondolása érdekében pedig a résztvevők több konzervet vetettek össze a képernyőmegosztással mutatott képek alapján. A továbbiakban (1. táblázat) ismertetjük a zöldségkonzervek megfelelő csomagolásának fontosabb jellemzőit a piacon már jelenlévő konzervek mintájára.

A konzervek csomagolásának fontos tényezői a fókuszesoportos kutatás alapján (Important Factors in Canned Food Packaging Based on Focus Group Research)

\section{Szempontok \\ (Factors) \\ A fókuszcsoport válaszai (Focus group responses)}

\section{A hívószavak fontossá- ga (The importance of buzzwords)} dolása (The concept of packaging)
Legyen hangutánzó szó (roppanós) vagy intenzíven fejezze ki az ízélményt (szuperédes).

Előnyös elhelyezni a termék megnevezése előtt (zsenge borsó). Ne legyen erőltetett (finom) és váltson ki kíváncsiságot (új, újdonság, limitált). (Be it an imitative word (crunchy) or intensely express the taste experience (super sweet). It is preferable to place it before the name of the product (firstling peas). Do not be forced (tasty) and arouse curiosity (new, novelty, limited).)

A logó után maga a termék megjelenítése (pl. kanálban, tálban, vagy csak egymásra halmozva) az első, amit megfigyel egy átlag fogyasztó. A színek legyenek feltűnőek, de természetességet és frissességet sugározzanak (famintázat - otthon melege). Kedvelt napjainkban a minimalista, letisztult irányzat, ahol a „szem megpihen”. Előnnyel szolgál a letéphető fedél is. (After the logo, the display of the product itself (e.g., in a spoon, bowl, or just stacked) is the first thing an average consumer observes. The colors should be striking but radiate naturalness and freshness (wood pattern - warmth at home). Nowadays, the minimalist, refined trend is popular where the "eyes rest". The tear-off lid is also an advantage.)
További információk megjelenítése (Display further information)
A tápértéktáblázat legyen egyszerü és letisztult. Érdemes a közösségi médiás és egyéb elérhetőségeket ikonokkal, akár QR kóddal feltűntetni. Nem árt továbbá előnyöket és érdekes információkat is felsorolni röviden, átláthatóan. (The nutrition facts should be simple and clear. If you want to include social media and other contact information, use icons or even a $Q R$ code. It is worth listing benefits and impressive information in a short, transparent way.)

Forrás (Source): Saját szerkesztés a fókuszcsoportos kutatás alapján, 2021 (Authors' own compilation based on the focus group, 2021) 
A leendő só- és cukormentes zöldségkonzervekről a résztvevők első véleménye, hogy a só és cukor hiánya ízben változásokat okozhat (pl. sótlan, nem elég édes). Emellett bizonytalanok az íz érdekében használt helyettesítések módszereiben. Az egyetemisták a bevezetés szakaszánál szükséges kommunikációhoz a dallamok és más hangi effektek használatát ajánlották. Az üzleteken belül pedig a leghatásosabb módszernek a többi konzerv mellé történő kihelyezést vélik, mivel a mentes vagy speciális termékek polcait nem ismerik.

A márka-megszemélyesítés során a résztvevőknek elképzelték a tipikus zöldségkon- zerv-fogyasztó személyt, majd demográfiai jellemzőket, érdeklődési köröket határoztak meg. A csoport tagjai szerint a konzervfogyasztók életstílusa általában pörgős lehet és az időhiány miatt szeretnék hamar letudni a sütést-fözést. A háttérben számos dolog állhat még, ez lehet a sok házimunka, a kevés konyhai tapasztalat, a rohanó élet, munka, tanulás, család és így tovább. Ezek alapján a résztvevők három kategóriát állapítottak meg (3. ábra), akik a tipikus konzervfogyasztók csoportjának nagy részét lefedhetik.

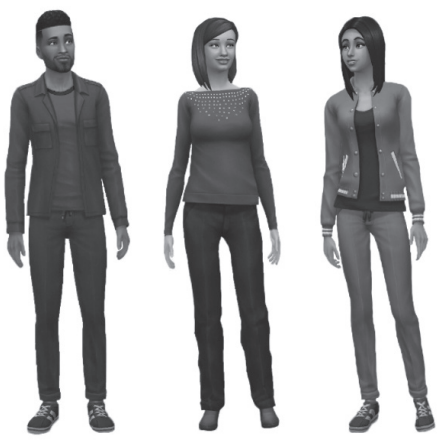

1. ÁBRA

\section{A tipikus konzervfogyasztók megszemélyesítése (Personalization of Typical Canned Food Consumers)}

Forrás (Source): Saját szerkesztés a fókuszcsoportos kutatás alapján, 2021 (Authors' own compilation based on the focus group, 2021)

Megjegyzés (Note): A bal oldalon: agglegény; középen: egészségtudatos anya; jobb oldalon: fiatal felnőtt hölgy. (On the left: bachelor; in the middle: health conscious mother; on the right: young adult lady.)

Az első személy az agglegény típus (bal oldali karakter), aki nem sokat fóz, így előnyben részesíti a készételeket. Sokat dolgozik, kevés a szabadideje, így szereti a praktikus megoldásokat, de nem feltétlenül él egészségtudatos életmódot. A második konzervfogyasztónk az egészségtudatos anya (középső karakter), aki próbál az idejével - talán a pénzével is spórolni, hiszen a házimunkára, a munkára és a gyerekekre is szeretne időt szánni a tudatos bevásárlás mellett. Végül a harmadik személy, akit megállapítottak a fókuszcsoport tagjai a fiatal felnőtt hölgy (jobb oldali karakter) volt. Feltehetőleg a tanulás, a szórakozás és a karrierépítés mellett nincs sok ideje főzni, kevés tapasztalata van a konyhában és egyszerü ételt keres a boltok polcain, számára nem olyan fon- tos a friss zöldségek fogyasztása. E három csoport kiemelt karakterei, mint ahogy írtuk, nem fedi le a teljes keresletet a zöldségkonzervekre vonatkozóan, viszont támpontot adhat a célcsoport meghatározására.

Összegezve a tipikus konzervfogyasztó karaktereket és a mentes élelmiszerek fogyasztóit, a metszetben jobban kiemelkedik egyrészt az idő hiánya, az egészségtudatosságra való törekvés vagy a divat szerinti táplálkozás (pl. látta másoktól). Másrészt a mentes konzervfogyasztóknál egyaránt fennállhatnak a fogyasztás hátterében a különböző táplálkozási problémák.

Végezetül a szituációs feladatból megállapítottuk, hogy a résztvevők szerint a szokásoktól, a sablonos étkezéstól és az adott életmódtól eleinte nehéz megszabadulni. A túlzott só- és 
cukorbevitel egyike a rossz tradícióknak és számos negatív következménnyel járhatnak, amelyekből több említésre is került a szituáció alatt. Vásárlás során nagy motivációt nyújthat az árban elenyésző különbség, hiszen ekkor a fogyasztók hajlamosabbak lehetnek a cukor- és sómentes termékek kipróbálására. Véleményük szerint a mentes zöldségkonzervek megoldást jelenthetnek az élelmiszerekben megbúvó cukor és só kikerülésére, ezzel is beépítve életünkbe a tudatos vásárlást és étkezést.

\section{KöVETKEZTETÉSEK ÉS JAVASLATOK - CONCLUSIONS AND PROPOSALS}

A bevezetésben megfogalmazott három kérdésünkre szekunder és primer kutatásokkal kerestük a válaszokat.

$\mathrm{Az}$ egyetemisták álláspontját vizsgálva megtudtuk, hogy azok a fogyasztók nagyobb hajlandóságot mutatnak a konzervvásárlásra, akiknek a szülei is rendszeresen vásárolták a konzerv termékeket (DRURY et al., 2018). Az első kérdésünket illetően leginkább a fókuszcsoport alapján jutottunk következtetésekre. Az egyetemisták szerint a konzervek időt takarítanak meg és könnyü a használatuk, azonban a friss zöldségeknél rosszabb minőséget párosítanak hozzájuk és csupán néhány felhasználási módját ismerik. A hallgatók úgy vélték, hogy sok sót és cukrot fogyasztanak. Bár ennek csökkentésére megoldást nyújtana a mentes konzerv, mégis bizalmatlanság lép fel, ugyanis nem tudják, hogy a csökkentésére, megvonására milyen módon jutnak el a vállalatok. Azt javasoljuk a konzervgyártók számára, hogy hívják fel a figyelmet a mentes termékek előnyeire, a gyártási folyamatokra, illetve a helyettesítés, kihagyás módjaira (pl. minőségi, természetes, új zöldségek termesztése, hogy ne legyen szükség só, cukor hozzáadására). Mindez a magasabb árazásra is magyarázatot adhat, mivel a fiatalok úgy vélik, hogy a mentes termékek esetében a magasabb ár csupán marketing eszköz.

A második kérdés kapcsán a só- és cukormentes zöldségkonzerv elképzelhető magyar fogyasztóit kutattuk, így egyrészt a só és cukor nélkül táplálkozó csoportnak, másrészt a tipikus konzervfogyasztóknak jártunk utána. A szakirodalmi (TEMESI, 2010; TEMESI és SZENTE, 2013; KÉRI, 2018) és a szakértői interjús kutatások alapján összességében a 18-40 év közötti korosztály rohanó életet élő, jó módú és egészségtudatos fogyasztóit javasoljuk a mentes konzervek célcsoportjának. Továbbá a szakértői interjú és a netnográfiás kutatás alapján azok a személyek is célközönséget alkothatnak, akik táplálkozási, egészségügyi problémával (TÖRŐCSIK, 2011; KSH, 2019a; KSH, 2019b) rendelkeznek, ugyanis számukra megoldást nyújthatnak a só- és cukormentes termékek. Gondot okozhat, hogy a fogyasztók a konzerveket általában nem sorolják az „egészséges” élelmiszerek közé (KOHLNÉ PAPP és GYÁNYI, 2017). Azonban a primer kutatások alapján a mentes termékeket egészségtudatosnak véli a társadalom. A sótól és cukortól mentes konzervekre nézve pozitívumként hat az egészséges kategorizálás, így azt ajánljunk, hogy a kommunikációra kiemelt figyelmet szánjanak a vállalatok, hogy a mentes konzerveket a fogyasztók az egészségtudatos táplálkozásba beilleszthető elemként értékeljék.

Végül a harmadik kérdésnél kifejezetten a kommunikációra írtunk javaslatokat. A sótól és cukortól mentes konzervekre pozitívan hat az egészséges kategorizálás, azonban a mentesség hangsúlyozása ellenkező hatást is kiválthat, erre pedig a szakirodalom (PRIVEN et al., 2015; KOCSIS, 2017), a szakértő és a fókuszcsoport alanyai is rávilágítottak. Tehát a mentes konzerveket úgy kell bemutatni a fogyasztóknak, hogy kevésbé kapjon hangsúlyt a só és cukor hiánya. Ehhez segítségként a fókuszcsoport is említett (1. táblázat) néhány élvezeti értéket, természetességet és egyéb előnyt kiemelő hívószavakat (pl. szuperédes, roppanós, újdonság). A netnográfia és a fókuszcsoportos vizsgálatok alapján, amikor online kommunikációt alkalmaznak a vállalatok, érdemes a közösségi médiában (pl. Facebook, Instagram) a vizuális és az auditív észlelésre is hatni. Többek között a netnográfiás vizsgálat alapján javasoljuk receptötletek, praktikák és tanácsok átadását, amelyhez akár hiteles tanácsadókat, orvosokat és dietetikusokat is felkérhetnek, de olyan véleményvezéreket is, akik valamilyen betegségben szenvednek (pl. cukorbetegség), hogy a fogyasztók a bizalmon túl azonosulni is 
tudjanak velük. Az offline, azaz hagyományos kommunikációnál javasoljuk a kóstoltatást, amit a primer kutatásaink is igazolnak, ugyanis a fogyasztók nagy szerepet tulajdonítanak a kipróbálás erejének. Ha megtaláltak egy új terméket a boltok polcain, akkor szívesen öszszehasonlítanák a már ismertekkel, ez pedig arra enged következtetni, hogy az üzletekben történő kihelyezés a hagyományos konzervek mellett lenne hatékony, így a vásárlók könnyedén összevethetik és megtalálhatják a mentes konzerveket, amivel a szakértő is egyetértett az interjú során.

A kommunikációnál összességében figyelni kell a megfelelő hívószavakra, hogy a mentesség hangsúlyozása ne érje negatívan a fogyasztók ízérzékelését. Emellett a szakértő és a szakirodalom alapján az információellátottságot, az ismeretterjesztést és az edukációt is gondosan fel kell építeni a fogyasztók bizalmának megtartása, az újszerú termékek elfogadása, illetve a tévhitek (KOHLNÉ PAPP és GYÁNYI, 2017; HORVÁTH, 2018) eloszlatása érdekében.

A jövőben a kvalitatív irány bővítésével megismernénk például a kereskedőknek vagy a fogyasztók más generációinak a véleményét. A pontosabb célcsoportok kialakítása érdekében pedig egy kvantitatív kérdőíves felméréssel differenciálnánk a fogyasztói szerepköröket.

\section{6. ÖSSZEFOGLALÁS - SUMMARY}

A só- és cukormentes konzervek piaci igényeinek feltárásához és a bevezetés lehetőségeinek megismeréséhez végeztük el a kutatást, ahol célunk volt kiindulópontot nyújtani az olyan konzervipari vállalatoknak, akik a jövőben mentes zöldségkonzervek gyártása, forgalmazása mellett döntenének.

$\mathrm{Az}$ eredmények részben először a netnográfia során feltárt fogyasztói hozzászólásokat, bejegyzéseket vizsgáltuk. A szakértői interjú alpontban pedig egy konzervipari szakember számolt be a konzervek sajátosságairól és a só- illetve cukormentes termékekről. Végül a fókuszcsoportos kutatás eredményeit mutattuk be, ahol a résztvevők mind egyetemisták voltak.
A legfontosabb észrevételeink a célcsoportot, illetve a kommunikációt illetően fogalmazódtak meg. A só- és cukormentes konzervek célpiacát javaslataink szerint a 18-40 év közötti jó módú egészségtudatos fogyasztók alkothatják, akiknek többek között kedvező a konzervek időmegtakarító tulajdonsága. A bevezetés szakaszában hasznos lehet kóstoltatást alkalmazni és az online platformokon receptötleteket megosztani. Mivel a mentesség túlzott kihangsúlyozása hiányérzetet válthat ki a fogyasztókból, így érdemes megválogatni a kommunikációban használt hívószavakat.

\section{KöSZÖNETNYILVÁNíTÁs -}

\section{ACKNOWLEDGEMENT}

A publikáció elkészítését az EFOP-3.6.1-162016-00022 számú projekt támogatta. A projekt az Európai Unió támogatásával, az Európai Szociális Alap társfinanszírozásával valósult meg.

\section{IRODALOMJEGYZÉK - REFERENCES}

\section{AHA (American Heart Association):} How Much Sugar is Too Much? 2020. URL: https://www.heart.org/en/healthyliving/healthy-eating/eat-smart/sugar/ how-much-sugar-is-too-much (Letöltés dátuma: 2020.10.28.)

Csapóné Riskó, T. - Péntek, Á.: Kenyér és péksütemény fogyasztási szokások a gluténmentes diétában. Táplálkozásmarketing. 2018. 5 (1) 77-89. DOI: https://doi.org/10.20494/TM/5/1/6

Drury, R. H. - Brown, L. B. - Williams, P. - Eggett, D. - Richards, R.: College Students' Understandings of, Perceptions Towards, and Usage of Canned Foods Based on Exposure to Canned Foods During Childhood. Undergraduate Honors Theses. 28. 2018. 
Hoek, A. C. - Pearson, D. - James, S. W. - Lawrence, M. A. - Friel, S.: Shrinking the Food-Print: A Qualitative Study Into Consumer Perceptions, Experiences and Attitudes Towards Healthy and Environmentally Friendly Food Behaviours. Appetite. 2017. 108 117-131. DOI: https://doi.org/10.1016/j. appet.2016.09.030

Horváth, V.: Tévhitek 4. rész - Konzervek. Nemzeti Agrárgazdasági Kamara Lapja. 2018. 6 (5) 7 .

Kéri, G.: Influencer-marketing. Már csak rajtuk keresztül lehet bármit eladni? Új intézmény megszületóben Piac \& Profit Konferencia, Social Media - 2018. A romló elérések hatásos ellenszerei. Budapest 2018.09.06.

Kocsis, E.: Az egészségtudatosság hatása a kiskereskedelemre. In: Nielsen. 2017. https://www.nielsen.com/hu/hu/ insights/article/2017/health-awarenessin-retail/ (Letöltés dátuma: 2019.06.17.)

Kohlné Papp, I. - Gyányi, D.: Az egészséges étrend fogyasztói szempontjai. In: A magyar lakosság életmódja: táplálkozás, testmozgás és lélek. Fehér könyv a TÉT Platform Egyesület kutatásainak adatai alapján (Szerk.: Antal, E. - Bánáti, D. Rurik, I. - Pilling, R. - Novák, K.). TÉT Platform Egyesület, Budapest, 2017. 7780.

KSH: November 14-e a diabétesz világnapja. 2019a. URL: http://www.ksh.hu/ infografika/2020/infografika_diabetesz. pdf (Letöltés dátuma: 2020.11.14.)

KSH: Tehetünk az egészségünkért. 2019b. URL: https://www.ksh.hu/docs/hun/ xftp/idoszaki/elef/te_2019/index.html (Letöltés dátuma: 2020.11.14.)

KSH: Az egy főre jutó éves élelmiszerfogyasztás mennyisége régiók szerint. 2019c. URL: https://www.ksh.hu/docs/ hun/xstadat/xstadat_eves/i_zhco23c. html?down=9001.111328125 (Letöltve: 2021.01.27.)

Lehota, J.: Marketingkutatás az agrárgazdaságban. Mezőgazda Kiadó, Budapest, 2001.
Liem, D. G. - Miremadi, F. - Zandstra, E. H. - Keast, R. S.: Health Labelling can Influence Taste Perception and Use of Table Salt for Reduced-Sodium Products. Public Health Nutrition. 2012. 15 (12) 2340-2347. DOI: https://doi. org/10.1017/S136898001200064X

Lipowski, M. - Bondos, I.: The Influence of Perceived Media Richness of Marketing Channels on Online Channel Usage: Intergenerational Differences. Baltic Journal of Management. 2018. 13 (2) 169190. DOI: https://doi.org/10.1108/BJM04-2017-0127

OGYÉI: Országos Táplálkozás és Tápláltsági Állapot Vizsgálata. 2014. URL: https:// www.ogyei.gov.hu/otap_2014/ (Letöltés dátuma: 2019.01.17.)

Pagliaro, M.: An Industry in Transition: The Chemical Industry and the Megatrends Driving Its Forthcoming Transformation. Angewandte Chemie International Edition. 2019. 58 (33) 11154-11159. DOI: https://doi.org/10.1002/anie.201905032

Priven, M. - Baum, J. - Vieira, E. Fung, T. - Herbold, N.: The Influence of a Factitious Free-From Food Product Label on Consumer Perceptions of Healthfulness. Journal of the Academy of Nutrition and Dietetics. 2015. 115 (11) 1808-1814. DOI: https://doi. org/10.1016/j.jand.2015.03.013

ResearchCenter: Magyar közösségi média körkép. 2020. https://www. researchcenter.hu/en/cikkek/magyarkozossegi-media-korkep/ (Letöltés dátuma: 2020.12.11.)

Szakály, Z. - Kiss, M. - Jasák, H.: Funkcionális élelmiszerek, fogyasztói attitűdök és személyre szabott táplálkozás. Táplálkozásmarketing. 2014. 1 (1-2) 3-17. DOI: https://doi.org/10.20494/TM/1/1$2 / 1$

Szakály, Z.: Trendek és tendenciák a funkcionális élelmiszerek piacán: Mit vár el a hazai fogyasztó? Élelmiszer, Táplálkozás és Marketing. 2008. 5 (2-3) 3-11. 
Boros, H. M. - FEHÉr, A.

Temesi, Á. - Biacs, P. - Szente, V.: A konzervipari termékek és a konzervek fogyasztói értelmezése. Élelmiszervizsgálati Közlemények. 2010. 56 (1) 24-34.

Temesi, Á.: A konzervipar által előállított funkcionális élelmiszerek marketinglehetőségei. Doktori disszertáció, Gazdálkodás- és Szervezéstudományok Doktori Iskola, Kaposvár, 2010.
Temesi, Á. - Szente, V.: Marketing aspects of functional canned food industrial products. Marketing \& Menedzsment. 2013. 47 (1) 46-53.

Törőcsik, M.: Fogyasztói magatartás Insight, trendek, vásárlók. Akadémiai Kiadó, Budapest, 2011.

WWF: The six livewell principles. 2020. URL: https://www.wwf.org.uk/what-wedo/livewell\#the-six-livewell-principles (Letöltés dátuma: 2020. 10.25.) 